\title{
Priapism due to glyceryl trinitrate in adult intensive care unit: A case report
}

\author{
Erdogan Aglamis ${ }^{1}$, , Cemal Tasdemir², Mehmet Ozgur Yucel ${ }^{3}$, Mehmet Sezai Ogras ${ }^{1}$, \\ Ercan Erdogan ${ }^{4}$
}

${ }^{1}$ Department of urology, Elazig Education and Research Hospital, Elazig, Turkey
2 Department of urology, Inonu University, Medical Faculty, Malatya, Turkey
${ }^{3}$ Department of urology, Adiyaman Education and Research Hospital, Adiyaman, Turkey
${ }^{4}$ Department of neurology, Elazig Education and Research Hospital, Elazig, Turkey

\section{Email address:}

uroloji23@yahoo.com (E.Aglamis), tasdemrcemal@yahoo.com (C. Tasdemir),mozyucel@yahoo.com (M. O. Yucel), sezaiogras@mynet.com (M. S. Ogras), elerdogan@mynet.com (E. Erdogan)

\section{To cite this article:}

Erdogan Aglamis, Cemal Tasdemir, Mehmet Ozgur Yucel, Mehmet Sezai Ogras, Ercan Erdogan. Priapism due to Glyceryl Trinitrate in Adult Intensive Care Unit: A Case Report. Clinical Medicine Research. Vol. 3, No. 1, 2014, pp. 9-11. doi: 10.11648/j.cmr.20140301.13

\begin{abstract}
Priapism is a prolonged penile erection without sexual stimulation. Two forms of priapism are recognized: veno-occlusive or low-flow priapism and arterial or high-flow priapism. High-flow (arterial) priapism is usually the result of straddle injury. Treatment of high-flow priapism may be elective Low-flow priapism is usually related to sickle cell disease, haemoglobinopathies, neoplastic syndrome, psychotropic medication, anticoagulant therapy, or idiopathic causes. Low-flow priapism is a case of urologic emergency and priapism must be treated as emergency. A 52-year-old man was admitted to the neurology intensive care unit with the diagnosis of stroke. Glyceryl trinitrate was applied to the patient for the treatment of hypertension. In our case, Low-flow priapisms were completely due to glyceryl trinitrate therapy applied at the insensive care. We report a case of prolonged low-flow priapism induced by Glyceryl trinitrate. In literature, this is the first report of glyceryl trinitrate-associated priapism.
\end{abstract}

Keywords: Priapism, Glyceryl Trinitrate, Intensive Care Unit

\section{Introduction}

Priapism is a prolonged penile erection without sexual stimulation and it is a pathological condition [1]. Priapism is a rare condition that can be seen in all age groups [1]. There are two types of priapism: ischemic priapism (venoocclusive, low flow) and nonischemic priapism (arterial, high flow) [2]. Low flow priapism is a case of urologic emergency that must be treated immediately [3]. Malignancies, trauma, some drugs (trazodone, prazosin, heparin etc) and various haematologicial diseases (leukemia, sickle cell anemia etc) can cause to priapism [4]. Glyceryl trinitrate that used in patients with hypertension and acute stroke is cerebral and systemic vasodilator drug [5].

In current report, we report that one patient developed priapism of therapy with glyceryl trinitrate (20-mg, intravenous infusion). In literature, this is the first report of glyceryl trinitrate-associated priapism.

\section{Case Report}

A 52-year-old man a history of amlodipin-treated hypertension. He was admitted to the neurology intensive care unit with the diagnosis of stroke. Glyceryl trinitrate was applied to the patient for the treatment of hypertension. After that, The patient was consulted to our clinic because of the priapism. The patient reported no history except hypertension (HT) and diabetes mellitus (DM). He denied taking antipsychotics or antidepressants, and alcohol or cocaine abuse. He also denied a history of intracavernous drug injection, malignancies, haematological and cerebrovascular diseases. In our case, priapisms were completely due to glyceryl trinitrate therapy applied at the insensive care. Physical examination revealed a rigid penis and flaccid glans associated with pain. Blood gas analysis of aspirated intracorporeal blood showed a $\mathrm{pH}$ of $6.8, \mathrm{pO}_{2}$ of 29 $\mathrm{mmHg}$, and $\mathrm{pCO}_{2}$ of $78 \mathrm{mmHg}$. Laboratory tests also showed normal peripheral blood differential cell count, no 
evidence of hemolysis or immature cells on the blood smear, and a negative urinalysis. Low-flow priapism was suspected (Table 1). Urgent treatment was performed by drainage and washout procedures of the corpora cavernosa. After aspiration, detumescence was achieved and the priapism resolved. The next day, glyceryl trinitrate therapy was continued, there was much bruising but no recurrence of symptoms. After four weeks, the patient died of cardiopulmonary arrest.

Table 1. Metabolic and hemodynamic characteristics of case.

\begin{tabular}{lc}
\hline & Finding \\
\hline Age & 52 \\
Pulsation & - \\
Palpation & Rigid \\
Viscosity (Intracavernal blood) & High \\
$\mathrm{pH}_{\text {(Intracavernal blood) }}$ & 6.8 \\
$\mathrm{pO}_{2}$ (Intracavernal blood) & $29 \mathrm{mmHg}$ \\
$\mathrm{pCO}_{2}$ (Intracavernal blood) & $78 \mathrm{mmHg}$ \\
Type of priapism & Ischemic (Low flow) \\
Treatment & Drainage and washout \\
\hline
\end{tabular}

\section{Discussion}

Priapism is caused by occlusion of venous system drainage in penile corpora cavernosa $[3,6,7,8]$. Alpha-1 adrenoreceptor blockage, blood dyscrasias and blockage in the penile venous system can cause to priapism $[3,6,8]$. Glyceryl trinitrate increases the release of nitric oxide and leads to relaxing smooth muscle of penile vascular tissue $[9,10]$. Dysregulation of penile vascular system can cause to ischemia, hypoxia and acidosis in penile erectile tissue and can induced priapism [6,8]. Prolonged ( $>24$ to 48 hours) penile corporeal ischemia may lead to fibrosis and destruction of the penile erectile tissue and may occur continuous erectile dysfunction [3].

Two forms of priapism are recognized: veno-occlusive or low-flow priapism and arterial or high-flow priapism [11,12]. High-flow (arterial) priapism is usually the result of straddle injury and is characterized by a painless, persistent semi-rigid erection. Because no ischemia results, treatment of this type of priapism may be elective [13]. However, low-flow priapism is a urologic emergency. The long-term sequelae of this more painful condition include erectile dysfunction or repeated episodes of prolonged priapism (Table 2) [3,14]. Etiologies of low-flow priapism are the various medical conditions including sickle cell disease and other hemoglobinopathies, malignancy, medication, and idiopathic causes $[3,15]$. It has been reported that common medications cause priapism include phenothiazines, antihypertensive agents, and anticoagulants [3,16]. Also intracavernous vasoactive agents (alprostadil, papaverine, prostaglandin E1 and phentolamin etc.) may cause to priapism [3,17].

Table 2. Classification of priapism [3].

\begin{tabular}{lcc}
\hline & $\begin{array}{c}\text { Ischemic (Low } \\
\text { flow) }\end{array}$ & $\begin{array}{c}\text { Nonischemic(High } \\
\text { flow) }\end{array}$ \\
\hline Pain & Painful & Painless \\
Pulsation & - & + \\
Palpation & Rigid & Semi-rigid \\
Viscosity (Intracavernal & High & Low \\
blood) & $<7.0$ & $>7.0$ \\
pH (Intracavernal blood) & $<60$ & $>60$ \\
$\mathrm{pO}_{2}$ (Intracavernal blood) & $>70$ & $<70$ \\
$\mathrm{pCO}_{2}$ (Intracavernal blood) & Low & High \\
Sonography; Arterial inflow $_{\mathrm{Cavernosography;} \text { Venous }}$ & Closed & Open \\
outflow & Immediately & Elective \\
Treatment & & \\
\hline
\end{tabular}

Assessment of the patient with priapism should include searching for one or more of the common risk factors, a detailed history and physical examination. Blood gas analysis of aspirated intracorporeal blood can help differentiate between high-flow and low flow priapism $[3,18]$. Treatment of priapism should be based on the underlying cause. Normally, low-flow priapism is treated with intracavernous vasoconstrictive drugs. Also it is treated with surgical shunting $[3,19,20,21]$.

\section{Conclusion}

As a result, priapism is a case of urologic emergency and priapism must be treated as emergency. Glyceryl trinitrate is a drug used to treat hypertension. Priapism in male patients may develop after the application of glyceryl trinitrate. Patients may be unconscious in intensive care units. Therefore, priapism must be checked at follow-up of patients because early diagnosis and treatment of priapism can prevent the formation of erectile dysfunction.

\section{Conflict of Interest}

The authors of declare no conflict of interest.

\section{References}

[1] Eland IA, Van Der Lei J, Stricker BH, Sturkenboom MJ. Incidence of priapism in the general population. Urology 2001; 57: 970-972.

[2] Aktoz T, Tepeler A, Gundogdu EO, Ozkuvanci U, Muslumanoglu AY. Priapism in the newborn: management and review of literature. Andrologia 2011; 43: 65-67.

[3] Van Der Horst C, Stuebinger H, Seif C, Melchior D, F.J. Martinez-Portillo FJ, Juenemann KP. Priapism-etiology, pathophysiology and management. Int Braz J Urol. 2003; 29: 391-400. 
[4] Bschleipfer TH, Hauck EW, Diemer TH, et al. Heparin-induced priapism. Int J Impot Res 2001; 13: 357-359.

[5] Willmot M, Ghadam A, Whysall B, Clarke W, Wardlaw J, Bath PMW. Transdermal Glyceryl Trinitrate Lowers Blood Pressure and Maintains Cerebral Blood Flow in Recent Stroke. Hypertension. 2006; 47: 1209-1215.

[6] Yuan J, Desouza R, Westney OL et al. Insights of priapism mechanism and rationale treatment for recurrent priapism. Asian J Androl 2008; 10: 88-101.

[7] Kogeorgos J, Alwis CD. Priapism and psychotropic medication. B J Psych 1986; 149: 241-243.

[8] Torun F, Yilmaz E, Gumus E. Priapism due to a Single Dose of Queti apine: A Case Report. Turk Psikiyatri Derg 2011; 22(3): 195-9.

[9] Brenner GM, Stevens CW. Pharmacology. 4th ed. Philadelphia: Elsevier Saunders, 2012, p 104

[10] Gruetter CA, Gruetter DY, Lyon JE, Kadowitz PJ, Ignarro LJ. Relationship between cyclic guanosine 3':5'-monophosphate formation and relaxation of coronary arterial smooth muscle by glyceryl trinitrate, nitroprusside, nitrite and nitric oxide: effects of methylene blue and methemoglobin. J Pharmacol Exp Ther 1981; 219 (1): 181-186

[11] Hauri D, Spycher M, Bruhlmann W. Erection and priapism: a new physiopathological concept. Urol Int 1983; 38: 138-45.

[12] Golash A, Gray R, Ruttley MS, Jenkins BJ. Traumatic priapism: an unusual cycling injury. Br J Sports Med 2000; 34: $310-1$.
[13] Harmon WJ, Nehra A. Priapism: diagnosis and management. Mayo Clin Proc 1997; 72: 350-5.

[14] Pranav NK, Sean OH. Priapism after androstenedione intake for athletic performance enhancement. Ann Emerg Med 2000; 35: 391-3.1. 15 .

[15] Fowler JE, Koshy M, Strub M, et al. Priapism associated with the sickle cell hemoglobinopathies: prevalence, natural history and sequelae. J Urol 1991; 145: 65-8.

[16] O'Brien WM, O'Connor KP, Lynch JH. Priapism: current concepts. Ann Emerg Med 1989; 18: 980-3.

[17] Hekal IA, Meuleman EJH. Idiopathic Low-Flow Priapism in Prepuberty: A Case Report and a Review of Literature. Adv Urol 2008; doi:10.1155/2008/549861

[18] Mulhall JP, Honig SC. Priapism: Etiology and management. Acad Emerg Med 1996; 3: 810-6.1.21.

[19] Montague DK, Jarow J, Broderick GA, et al. American Urological Association guideline on the management of priapism. J Urol 2003; 170: 1318-1324.

[20] Stuttering Priapism: Insights into Pathogenesis and Management. Morrison BF, Burnett AL. Curr Urol Rep 2012 May 31.

[21] Tay YK, Spernat D, Rzetelski-West K, Appu S, Love C. Acute management of priapism in men. BJU Int 2012 Apr; 109 Suppl 3: 15-21. 